\title{
PERAN BOOKLET TERHADAP PENGETAHUAN, SIKAP, PERILAKU JUMANTIK-PSN DAN KEBERADAAN JENTIK DI PANARUNG, KOTA PALANGKA RAYA
}

\author{
Natalansyah*, Yongwan Nyamin \\ Program Studi DIV Keperawatan, Jurusan Keperawatan, \\ Poltekkes Kemenkes Palangka Raya, Kota Palangka Raya, 73111, Indonesia \\ E-mail: natalansyahpoltekkespraya@yahoo.com
}

\begin{abstract}
ABSTRAK
Latar Belakang : Demam Berdarah Dengue (DBD) merupakan salah satu penyakit menular dan yang menjadi masalah kesehatan masyarakat yang utama di Indonesia. Incidence Rate DBD di Kota Palangka Raya selama tiga tahun terus meningkat menjadi 62,76\% dan Case Fatality Rate 1,23\% di tahun 2016. Hal ini karena peran serta masyarakat dalam kegiatan PSN belum dilaksanakan dengan optimal. Salah satu langkah strategis dalam mengoptimalkan peran serta masyarakat dalam pengendalian DBD adalah pemberdayaan anak sekolah dengan media Booklet untuk meningkatkan perilaku Jumantik-PSN anak sekolah. Tujuan: Penelitian ini bertujuan untuk mengetahui efektivitas penggunan booklet dalam meningkatkan pengetahuan, sikap, perilaku jumantik-PSN anak sekolah dan keberadaan jentik di SDN 1 dan 2 Panarung Kota Palangka Raya. Metode: Penelitian ini menggunakan desain kuasi eksperimental two group pre-posttest design. Perhitungan besar sampel menggunakan Uji Hipotesis beda rata-rata dua kelompok independent dengan kekuatan uji ( $\beta$ ) 90\%, sehingga didapatkan besar sampel berjumlah 60 orang siswa SD kelas lima, masing-masing 30 kelompok eksperimen dan kontrol. Instrumen yang digunakan yaitu kuesioner, lembar checklist, booklet. Uji statistik $t$-test digunakan untuk mengetahui perbedaan skor pengetahuan, sikap dan perilaku. Hasil: uji statistic menunjukkan terdapat perbedaan skor pengetahuan, sikap antara kelompok kontrol dengan kelompok intervensi $(p=0,002 \mathrm{dan} p=0,031)$. Uji statistik menunjukkan terdapat perbedaan skor perilaku $(\mathrm{p}=0,014)$ dan uji chi square menunjukkan perbedaan proporsi keberadaan jentik antara kelompok intervensi dengan kelompok kontrol $(p=0,004)$. Diskusi: Siswa Pemantau Jentik (sismantik) adalah pemberdayaan siswa sekolah dasar untuk menjadi juru pemantau jentik. Pemberian konseling dengan booklet secara signifikan membantu meningkatkan pengetahuan, sikap dan perilaku Juru Pemantau Jentik-Pemberantasan Sarang Nyamuk (Jumantik-PSN) anak sekolah. Simpulan: Booklet dapat menjadi salah satu alternatif media edukasi untuk menyampaikan informasi yang berkaitan Jumantik-PSN anak dan membantu meningkatkan pengetahuan, sikap, perilaku dan menurunkan keberadaan jentik.
\end{abstract}

Kata Kunci: Pengetahuan, Sikap, Perilaku, Jumantik, Booklet

The Role of Booklet in Increasing the Knowledge, Attitude Behavior of Jumantik-PSN and the Preference of Larvae in Panarung, Palangka Raya City

\section{ABSTRACT}

Background: Dengue Haemorrhagic Fever (DHF) is one of the most contagious diseases and is a major public health problem in Indonesia. Incidence Rate of DHF in Palangka Raya city for three years continues to increase become $62,7 \%$ and case fatality rate 1,23\% in 2016, this is because of community participation as Juru Pemantau JentikPemberantasan Sarang Nyamuk (Jumantik-PSN) has not been implemented optimally. One of the strategic steps in optimizing the community participation in the control of DHF is empowerment of students with Booklet to improve the behavior of Jumantik-PSN school children. Objective: This study aimed to determine the effectiveness of the use of booklets in increasing the knowledge, attitude, behavior of jumantik-PSN in school children and the presence of larvae in SDN 1 and 2 Panarung Palangka Raya City. Method: This study uses a quasi experimental two group pre- 
posttest design. The sample size calculation uses the Hypothesis Test with an average difference of two independent groups with power of test ( $\beta$ ) $90 \%$, so that a sample size of 60 fifth grade elementary school students is obtained, each with 30 experimental and control groups. The instruments used were questionnaire, checklist sheet, booklet. Statistical test $t$-test is used to determine differences in scores of knowledge and attitudes; mann whitney test used to determine differences in scores of behavior. Result: There were differences score of knowledge and attitude between control group and intervention group ( $p=0,002$ and $p=0,031)$, there were difference of behavior score $(p=0,014)$ and chi square test showed different proportion of larva between the intervention group and the control group ( $p=0.004)$. Discussion: Sismantik is the empowerment of elementary school students. Counseling with booklets significantly helped to increase the knowledge, attitude and behavior of Jumantik-PSN of school children. Conclusion: Booklet can be one of education media alternative to convey information relating Jumantik-PSN school children so that can help improve knowledge, attitude, behavior and decrease the existence of larva.

Keywords: knowledge, attitude, behavior, jumantik, booklet

\section{LATAR BELAKANG}

Demam Berdarah Dengue (DBD) merupakan salah satu penyakit menular dan yang menjadi masalah kesehatan masyarakat yang utama di Indonesia. DBD adalah penyakit yang disebabkan oleh virus dengue yang tergolong Arthropod-Borne Virus, genus Flavivirus. menurut data WHO, Asia pasifik memanggung $75 \%$ dari beban dengue di dunia antara tahun 2004-2010, sementara Indonesia dilaporkan sebagai negara ke-2 dengan kasus DBD terbesar diantara 30 negara wilayah endemis (Pusdatin, 2018).

Menurut Dinas Kesehatan Kalimantan Tengah (2016), tahun 2015 Incidence rate/ Angka Kesakitan sebesar 66,5 per 100.000 penduduk sedangkan pada tahun 2016 sebesar 69,1 per 100.000 penduduk, di atas angka kesakitan nasional sebesar $65 \% / 100.000$ penduduk. Kasus DBD di Kota Palangka Raya tahun (2016) sebanyak 217 orang dengan 2 orang meninggal. Jumlah kasus menurut kelompok umur terbanyak pada usia anak sekolah dan balita, kemudian dari penyebaran jumlah penderita per Puskesmas terbanyak 33 kasus terdapat di wilayah Kelurahan Panarung Kecamatan Jekan Palangka Raya (Dinas Kesehatan Kalimantan Tengah, 2016).

Dalam mewujudkan tujuh kegiatan pokok pengendalian DBD, ditentukan lima rencana pengembangan program antara lain meningkatkan peran serta masyarakat, mengaktifkan kembali kelompok kerja operasional (Pokjanal) DBD di berbagai tingkat administrasi, mendorong kegiatan pemberantasan sarang nyamuk (PSN) oleh sekolah dan pramuka, mendukung pengembangan vaksin serta meningkatkan kemampuan sumber daya manusia (SDM) pengendalian penyakit bersumber arbovirosis. Salah satu langkah optimalisasi peran serta masyarakat dalam mengendalian DBD adalah dengan memanfaatkan media pendidikan sebagai sarana penunjang, yang dapat merangsang pikiran, perasaan, perhatian, dan minat dari penerima materi, salah satu medianya penggunaan booklet jumantik-PSN DBD (Pusdatin, 2017).

Hasil penelitian yang dilakukan Malikatul menunjukkan pendidikan kesehatan menggunakan media booklet dapat meningkatkan pengetahuan (Malikatul, 2015). Penggunaan buku saku atau booklet sebagai media pendidikan dapat meningkatkan pengetahuan, sikap, dan perilaku. Hasil penelitian ini adalah terdapat perbedaan pengetahuan dan sikap jumantik kecil sebelum dan sesudah pemberian pelatihan pencegahan DBD di Madrasah Ibtidaiyah Negeri Ketitang. Berdasarkan latar belakang tersebut, maka penulis ingin melakukan penelitian mengenai peranan booklet dalam peningkatan 
Perilaku Jumantik-PSN anak sekolah dan keberadaan jentik di Kelurahan Panarung Kecamatan Pahandut Kota Palangka Raya.

\section{METODE}

Jenis dan disain penelitian ini adalah penelitian eksperimen tidak murni dengan kelompok kontrol (pretest-posttest only group design) (Lapau, 2012). Pretest dilakukan pada kelompok tersebut dan diikuti intervensi pada kelompok eksperimen. Setelah beberapa waktu dilakukan posttest pada kedua kelompok. Populasi pada penelitian ini adalah semua anak pada Sekolah Dasar di Kelurahan Panarung Kota Palangka Raya. Pengambilan sampel dalam penelitian ini dilakukan dengan cara simple random sampling atau pengambilan sampel secara acak sederhana, dengan kriteria inklusi anak berada pada jenjang kelas 5 SD dan bersedia ikut penelitian sesuai tata kerja. Besar sampel ditentukan berdasarkan perhitungan besar sampel uji hipotesis beda rata-rata dua kelompok independen (Lemeshow, dkk, 1993). Kekuatan uji yang digunakan yaitu sebesar $90 \%$, sehingga didapatkan 60 sampel, terdiri dari 30 sampel pada kelompok kontrol (SDN 1 Panarung) dan 30 sampel pada kelompok eksperimen (SDN 2 Panarung).

Penelitian dilaksanakan selama 8 minggu, dimulai sejak tanggal 8 Agustus 2018 sampai 28 September 2018. Pada penelitian ini data diperoleh dengan menggunakan angket, wawancara dan pengisian kuesioner saat sebelum dan sesudah perlakuan untuk mendapatkan data pengetahuan, sikap dan perilaku anak sekolah dasar kelas lima di kelurahan Panarung dan melakukan survei untuk mendapatkan data angka bebas jentik (ABJ) di lingkungan sekitar sekolah anak sebagai Jumantik-PSN sebelum dan sesudah telah mendapat perlakuan.

Instrumen penelitian terdiri dari 4 bagian. (1) Bagian A: yaitu berhubungan dengan karakteristik Peserta didik jumantik meliputi nama, umur, dan sumber informasi. (2) Bagian B: yaitu yang berkaitan dengan kemampuan (pengetahuan) peserta didik tentang PSN DBD dan pemeriksaan jentik sebanyak 15 pertanyaan. (3) Bagian C: Pertanyaan yang berkaitan dengan kemampuan (sikap) Jumantik-PSN anak sekolah 14 pertanyaan. Setiap pernyataan diberi skor skala Likert 1-4. (4) Bagian D: pertanyaan yang berkaitan dengan kemampuan (Praktek/perilaku nyata) peserta didik dalam melakukan pemeriksaan jentik sebanyak 6 pertanyaan.

Hasil uji coba instrumen dilakukan pada 35 orang siswa Kelas 5 Sekolah Dasar Negeri 4 (SDN 4) Menteng Palangka Raya Kota Palangka Raya menunjukkan hasil pada intrumen pengetahuan pertanyaan valid $(>0,329)$ dan reliabel (nilai 0,612). Instrumen sikap, menunjukkan hasil pertanyaan valid $(>0,329)$ dan reliabel (nilai 0,859 ). Instrumen perilaku, menunjukkan hasil pertanyaan valid $(>0,329)$ dan reliabel (nilai 0,642). Uji t, Mann Whitney dan chi square digunakan untuk menganalisis perbedaan pengetahuan, sikap, perilaku dan keberadaan jentik antara sebelum dan sesudah intervensi dilakukan. Penelitian ini telah lolos kaji etik penelitian dari Komite Etik Penelitian Fakultas Kedokteran Universitas Palangka Raya dengan Keterangan Kelaikan Etik Nomor 1043/UN24.9/KM/2017 pada tanggal 16 Juni 2017.

\section{HASIL \\ Gambaran Lokasi Penelitian}

Kelurahan Panarung merupakan salah satu dari 6 kelurahan yang berada di wilayah Kecamatan Pahandut Kota Palangka Raya, yang terdiri dari 52 Rukun Tetangga (RT) dan 14 (satu) Rukun Warga (RW) Jumlah penduduk sebesar 20.693 jiwa. Luas wilayah $23,50 \mathrm{Km}^{2}$ dengan kepadatan penduduk $880,55 / \mathrm{Km}^{2}$. Sarana pendidikan yang 
tersedia yaitu 7 buah SDN, 1 SD swasta, $2 \mathrm{MI}$ NU dan 1 SMPN. Sarana kesehatan terdiri dari 1 buah puskesmas induk "Panarung", 6 puskesmas pembantu (Pangaringan I, Pangaringan II, PCPR, Pinus, Plamboyan Bawah, Plamboyan Baru).

\section{Gambaran Karakteristik Responden}

Responden pada penelitian ini berjumlah 60 , yang terdiri dari 30 anak pada kelompok perlakuan (Pemberdayaan Anak Sekolah Dasar Sebagai Jumantik-PSN DBD) dan 30 anak pada kelompok kontrol. bila dillihat dari umur responden (kelas 5) rata-rata berusia 9-10 tahun, sedangkan untuk jenis kelamin lebih banyak perempuan (55\%) dibandingkan dengan Laki-laki (45\%). Kelompok perlakuan merupakan siswa pada SDN 1 Panarung dan kelompok kontrol merupakan siswa pada SDN 2 Panarung. Pemantauan jentik dilakukan selama 8 minggu, mulai tanggal 8 Agustus 2018 sampai 28 September 2018.

\section{Gambaran Pengetahuan, Sikap dan Perilaku Siswa}

\section{Sebelum Intervensi}

Tabel 1 menunjukkan Pengetahuan sebelum masa pemberian intervensi. Tingkat pengetahuan siswa pada kelompok kontrol, skor terendah 2 dan skor tertinggi 11. Rata-rata skor tingkat pengetahuan pada kelompok kontrol adalah 5,83 , dengan standar deviasi 2,052. Menggunakan derajat kepercayaan $95 \%$, peneliti percaya bahwa skor tingkat pengetahuan di populasi kelompok kontrol antara 5,07-6,66. Tingkat pengetahuan sebelum pada kelompok intervensi, skor terendah 2 dan skor tertinggi 8. Rata-rata skor tingkat pengetahuan pada kelompok perlakuan adalah 5,03 , dengan standar deviasi 1,84. Menggunakan derajat kepercayaan $95 \%$, peneliti percaya bahwa skor tingkat pengetahuan di populasi antara 4,34-5,72. Sikap sebelum masa pemberian intervensi, sikap siswa pada kelompok kontrol, skor terendah 22 dan skor tertinggi 56. Rata-rata skor sikap pada kelompok kontrol adalah 44,67, dengan standar deviasi 6,73 . Menggunakan derajat kepercayaan $95 \%$, peneliti percaya bahwa skor sikap di populasi kelompok kontrol antara 42,1547,18 .

Skor sikap pada kelompok perlakuan sebelum diberikan intervensi, skor terendah 37 dan skor tertinggi 54 . Rata-rata skor sikap pada kelompok perlakuan adalah 45,6, dengan standar deviasi 4,11. Menggunakan derajat kepercayaan $95 \%$, peneliti percaya bahwa skor sikap di populasi antara 44,0647,14 . Perilaku sebelum masa pemberian intervensi, perilaku siswa pada kelompok kontrol skor terendah 0 dan skor tertinggi 5. Rata-rata skor perilaku pada kelompok kontrol adalah 1,03 , dengan standar deviasi 1,15 . Menggunakan derajat kepercayaan $95 \%$, peneliti percaya bahwa skor perilaku di populasi yang tidak di beri intervensi (kelompok kontrol) antara 0,6-1,47. Skor perilaku pada kelompok perlakuan sebelum diberikan intervensi, skor terendah 0 dan skor tertinggi 4. Rata-rata skor perilaku pada kelompok perlakuan adalah 1,73, dengan standar deviasi 0,94. Menggunakan derajat kepercayaan $95 \%$, peneliti percaya bahwa skor sikap di populasi antara 1,382,09 . 
Tabel 1.

Gambaran Pengetahuan, Sikap dan Perilaku Siswa pada kelompok Kontrol dan Perlakuan Sebelum Intervensi

\begin{tabular}{|c|c|c|c|c|c|c|}
\hline Variabel & Kelompok & $\mathbf{N}$ & $\underset{\operatorname{Max}}{\operatorname{Min}-}$ & Mean & SD & $95 \%$ Cl Mean \\
\hline \multirow[t]{2}{*}{ Pengetahuan } & Kontrol & 30 & $2-11$ & 5,83 & 2,052 & $5,07-6,6$ \\
\hline & Perlakuan & 30 & $2-8$ & 5,03 & 1,84 & $4,34-5,72$ \\
\hline \multirow[t]{2}{*}{ Sikap } & Kontrol & 30 & $22-56$ & 44,67 & 6,73 & $42,15-47,18$ \\
\hline & Perlakuan & 30 & $37-54$ & 45,6 & 4,11 & $44,06-47,14$ \\
\hline \multirow[t]{2}{*}{ Perilaku } & Kontrol & 30 & $0-5$ & 1,03 & 1,15 & $0,6-1,47$ \\
\hline & Perlakuan & 30 & $0-4$ & 1,73 & 0,94 & $1,38-2,09$ \\
\hline
\end{tabular}

Keterangan :

Min: minimum; max: maksimum; mean: rata rata; SD: Standar deviasi; CI: Confident Interval

\section{Setelah Intervensi}

Dari Tabel 2 dapat diketahui bahwa pengetahuan setelah masa pemberian intervensi, tingkat pengetahuan siswa pada kelompok kontrol, skor terendah 3 dan skor tertinggi 10. Rata-rata skor tingkat pengetahuan pada kelompok kontrol adalah 6,43 , dengan standar deviasi 1,9 . Menggunakan derajat kepercayaan $95 \%$, peneliti percaya bahwa skor tingkat pengetahuan di populasi yang tidak diberi intervensi (kelompok kontrol) antara 5,727,15 . Tingkat pengetahuan pada kelompok perlakuan setelah diberikan intervensi, skor terendah 4 dan skor tertinggi 12 . Rata-rata skor tingkat pengetahuan pada kelompok perlakuan adalah 8,1, dengan standar deviasi 2,12. Menggunakan derajat kepercayaan $95 \%$, peneliti percaya bahwa skor tingkat pengetahuan di populasi setelah diberikan intervensi antara 7,31-8,89.

Sikap setelah masa pemberian intervensi, sikap siswa pada kelompok kontrol (tidak diberi intervensi), skor terendah 30 dan skor tertinggi 55. Rata-rata skor sikap pada kelompok kontrol adalah 44,23, dengan standar deviasi 6,51. Menggunakan derajat kepercayaan $95 \%$, peneliti percaya bahwa skor sikap di populasi yang tidak di beri intervensi (kelompok kontrol) antara 41,8-46,66.

Skor sikap pada kelompok perlakuan 
setelah diberikan intervensi, skor terendah 42 dan skor tertinggi 52 . Rata-rata skor sikap pada kelompok perlakuan adalah 47,17, dengan standar deviasi 3,03. Menggunakan derajat kepercayaan $95 \%$, peneliti percaya bahwa skor sikap di populasi antara 46,0448,3. Perilaku setelah masa pemberian intervensi, perilaku siswa pada kelompok kontrol (tidak diberi intervensi), skor terendah 0 dan skor tertinggi 3. Rata-rata skor perilaku pada kelompok kontrol adalah 1,13, dengan standar deviasi 0,93. Menggunakan derajat kepercayaan $95 \%$, peneliti percaya bahwa skor perilaku di populasi yang tidak diberi intervensi (kelompok kontrol) antara $0,78-1,48$. Skor perilaku pada kelompok perlakuan sebelum diberikan intervensi , skor terendah 0 dan skor tertinggi 5 . Ratarata skor perilaku pada kelompok perlakuan adalah 1,73, dengan standar deviasi 0,98. Menggunakan derajat kepercayaan 95\%, peneliti percaya bahwa skor sikap di populasi antara $1,37-2,1$.

Tabel 2.

Gambaran Pengetahuan, Sikap dan Perilaku Siswa pada kelompok Kontrol dan Perlakuan Setelah Intervensi

\begin{tabular}{|c|c|c|c|c|c|c|}
\hline Variabel & Kelompok & $\mathbf{n}$ & Min - Max & Mean & SD & $95 \%$ Cl Mean \\
\hline \multirow{2}{*}{ Pengetahuan } & Kontrol & 30 & $3-10$ & 6,43 & 1,9 & $5,72-7,15$ \\
\hline & Perlakuan & 30 & $4-12$ & 8,1 & 2,12 & $7,31-8,89$ \\
\hline \multirow{2}{*}{ Sikap } & Kontrol & 30 & $30-55$ & 44,23 & 6,51 & $41,8-46,66$ \\
\hline & Perlakuan & 30 & $42-52$ & 47,17 & 3,03 & $46,04-48,3$ \\
\hline \multirow{2}{*}{ Perilaku } & Kontrol & 30 & $0-3$ & 1,13 & 0,93 & $0,78-1,48$ \\
\hline & Perlakuan & 30 & $0-5$ & 1,73 & 0,98 & $137-2,1$ \\
\hline
\end{tabular}


Tabel 3.

Hasil Pemantauan jentik nyamuk pada kelompok perlakuan dan Kontrol

\begin{tabular}{|c|c|c|c|c|c|}
\hline \multirow{2}{*}{ Kelompok } & \multirow{2}{*}{$\mathbf{n}$} & \multicolumn{2}{|c|}{ Minggu 1} & \multicolumn{2}{|c|}{ Minggu 8} \\
\hline & & $\begin{array}{l}\text { Hasil positif } \\
\qquad(+) n(\%)\end{array}$ & $\begin{array}{c}\text { Hasil negatif (-) } \\
\text { n (\%) }\end{array}$ & $\begin{array}{l}\text { Hasil positif } \\
\qquad(+) n(\%)\end{array}$ & $\begin{array}{l}\text { Hasil negatif } \\
\qquad(-) \text { n (\%) }\end{array}$ \\
\hline Perlakuan & 30 & $14(47 \%)$ & $16(53 \%)$ & $7(28,12 \%)$ & $23(71,8 \%)$ \\
\hline Kontrol & 30 & $20(66 \%)$ & $10(34 \%)$ & $18(60 \%)$ & $12(40 \%)$ \\
\hline
\end{tabular}

Tabel 4.

Analisis Pengaruh Pemberdayaan Anak Sekolah Dasar Sebagai Jumantik-PSN Terhadap Perubahan Perilaku dan Sikap

\begin{tabular}{|c|c|c|c|c|c|c|}
\hline Variabel & & $\begin{array}{l}\text { Mean Skor } \\
(95 \% \mathrm{Cl})\end{array}$ & SD & $\begin{array}{l}\text { Levene } \\
\text { Test }\end{array}$ & Selisih & $\begin{array}{c}p \\
\text { Value }\end{array}$ \\
\hline \multirow{2}{*}{ Pengetahuan } & $\begin{array}{l}\text { Kelompok Kontrol } \\
(n=30)\end{array}$ & $\begin{array}{l}6,43 \\
(5,72-7,15)\end{array}$ & 1,9 & \multirow{2}{*}{$0,541^{*}$} & \multirow{2}{*}{$\begin{array}{c}1,66 \\
(0,62- \\
2,71)\end{array}$} & \multirow{2}{*}{0,002} \\
\hline & $\begin{array}{l}\text { Kelompok Intervensi } \\
(n=30)\end{array}$ & $\begin{array}{l}8,1 \\
(7,31-8,89)\end{array}$ & 2,12 & & & \\
\hline \multirow[b]{2}{*}{ Sikap } & $\begin{array}{l}\text { Kelompok Kontrol } \\
(n=30)\end{array}$ & $\begin{array}{l}44,23 \\
(41,8-46,66)\end{array}$ & 6,51 & \multirow[b]{2}{*}{$0,03^{a}$} & \multirow{2}{*}{$\begin{array}{c}2,933 \\
(0,28- \\
5,5)\end{array}$} & \multirow[b]{2}{*}{0,031} \\
\hline & $\begin{array}{l}\text { Kelompok Intervensi } \\
(\mathrm{n}=30)\end{array}$ & $\begin{array}{l}47,17 \\
(46,04-48,3)\end{array}$ & 3,03 & & & \\
\hline
\end{tabular}

Keterangan: uji normalitas sebaran data menggunakan shapiro wilk dan analisis menggunakan independent $t$-test, ${ }^{*}$ Levene test ataraf signifikan $>0,05$. 


\section{Pemantauan jentik nyamuk pada kelompok perlakuan dan kontrol}

Pemantauan jentik dilakukan pada dua tempat yaitu pertama di lingkungan rumah responden kelompok perlakuan dan yang kedua lingkungan rumah responden kelompok kontrol, sedangkan jenis kontainer yang diobservasi seperti bak mandi, bak WC, tempayan, ember dispenser, pot/vas bunga, ban bekas, botol/kaleng bekas.

Berdasarkan tabel 3 didapatkan hasil bahwa pada kelompok perlakuan, hasil pemantauan jentik nyamuk pada minggu ke- 1 ditemukan sebanyak $47 \%$ positif dan $53 \%$ negatif, sedangkan pada minggu ke- 8 ditemukan sebanyak $28,12 \%$ positif dan $71,8 \%$ negatif. Pada kelompok kontrol, hasil pemantauan jentik nyamuk pada minggu ke-1 ditemukan sebanyak $66 \%$ positif dan $34 \%$ negatif, sedangkan pada minggu ke- 8 ditemukan sebanyak $60 \%$ positif dan $40 \%$ negatif, semakin tinggi hasil pemantauan negatif atau angka bebas jentik (ABJ) maka semakin baik, kerena keberhasilan PSN DBD menurut Departemen Kesehatan (2005) antara lain dapat diukur dengan seberapa besar angka bebas jentik (ABJ), apabila ABJ lebih atau sama dengan 95\% diharapkan penularan DBD dapat dicegah atau dikurangi.

\begin{abstract}
Perbedaan Pengetahuan, Sikap, Perilaku dan Keberadaan Jentik Antara Kelompok Setelah Intervensi Pemberdayaan Sebagai Jumantik-PSN dengan Diberikan Booklet
\end{abstract}

Hasil analisis perbedaan pada kelompok kontrol dan perlakuan setelah diberdayakan sebagai jumantik PSN terdapat pada tabel 4.

Pengetahuan setelah masa intervensi, rata-rata skor pengetahuan pada siswa kelompok perlakuan Pemberdayaan Anak Sekolah Dasar Sebagai Jumantik-PSN lebih tinggi dibandingkan kelompok kontrol $(8,1$; $95 \% \mathrm{Cl} 7,31-8,89)$ dengan selisih 1,66. $95 \%$ interval selisih tersebut 0,62-2,71. Secara statistik rata-rata skor pengetahuan siswa kelompok perlakuan berbeda dengan kelompok kontrol. Hal ini dinyatakan dengan nilai $p$ value $<0,05$. Sikap setelah masa intervensi, rata-rata skor sikap pada siswa kelompok perlakuan Pemberdayaan Anak Sekolah Dasar Sebagai Jumantik-PSN lebih tinggi dibandingkan kelompok kontrol $(47,17 ; 95 \% \mathrm{Cl} 46,04-48,3)$ dengan selisih 2,933 . 95\% interval selisih tersebut $0,28-$ 5,5 . Secara statistik rata-rata skor sikap siswa kelompok perlakuan berbeda dengan kelompok kontrol, hal ini dinyatakan dengan $p$ value $<0.05$.

\section{Tabel 5. Analisis Pengaruh Pemberdayaan Anak SD Sebagai Jumantik-PSN dengan Booklet terhadap Perubahan Perilaku Siswa}

\begin{tabular}{|c|c|c|c|}
\hline Variabel & Kelompok & Mean rank & p Value \\
\hline \multirow{3}{*}{ Perilaku } & Kelompok Kontrol $(n=30)$ & 25,22 & \multirow{3}{*}{0,014} \\
\hline & & & \\
\hline & Kelompok Perlakuan $(n=30)$ & 35,78 & \\
\hline
\end{tabular}

Keterangan : uji normalitas sebaran data menggunakan shapiro wilk dan analisis menggunakan mann whitney $U$ 
Tabel 5 menunjukkan mean rank atau rata rata peringkat tiap kelompok, yaitu pada kelompok kesatu rata rata peringkatnya 25,22 lebih rendah dari pada rerata peringkat kelompok ke-2 yaitu 35,78. Perbedaan rerata peringkat kedua kelompok tersebut bermakna secara statistik dinyatakan dalam nilai $p$ value $0,014(<0,05)$. pengetahuan bahaya merokok pada remaja dengan signifikan $p$ value $=0,00(p<0,05)$. Penelitian yang dilakukan Susiana (2016) menunjukkan bahwa pemberian konseling dengan booklet secara signifikan membantu meningkatkan pengetahuan, perilaku dan kepatuhan pasien $(p<0,05)$ (Susiana, 2016). Penelitian lain menunjukkan bahwa terdapat

Tabel 6. Analisis Perbedaan Proporsi Angka Keberadaan Jentik antara Kelompok Kontrol dan Perlakuan sesudah Masa intervensi

\begin{tabular}{llll}
\hline $\mathbf{n}$ & Hasil + & Hasil - & p Value \\
\hline $\begin{array}{l}\text { Kontrol } \\
(\mathrm{n}=30)\end{array}$ & $\begin{array}{l}18 \\
(60 \%)\end{array}$ & $\begin{array}{l}12 \\
(40 \%)\end{array}$ \\
\hline $\begin{array}{l}\text { Intervensi } \\
(\mathrm{n}=30)\end{array}$ & 7 & & 0,004 \\
\hline
\end{tabular}

Ada perbedaan angka keberadaan jentik antara kelompok kontrol dan intervensi, hasil analisis statistik chi square menunjukkan nilai signifikan $p$ Value $0,004(<0,05)$.

\section{DISKUSI}

\section{Perbedaan Pengetahuan antara Kelom-} pok Intervensi dan Kontrol

Hasil penelitian yang dilakukan ini menemukan bahwa terdapat perbedaan signifikan skor pengetahuan antara kelompok perlakuan dan kelompok kontrol setelah diperdayakan sebagai Jumantik-PSN DBD, siswa yang diperdayakan sebagai jumantikPSN memiliki skor pengetahuan $(8,1 ; 95 \%$ Cl 7,31-8,89) lebih tinggi dibandingkan dengan skor pengetahuan $(6,43 ; 95 \%$ $5,72-7,15)$ siswa yang tidak diberdayakan sebagai jumantik PSN. Hal ini dinyatakan dengan nilai $p$ value $0,002(P<0,5)$. Hasil penelitian ini sejalan dengan hasil penelitian Wahyuni (2016) bahwa pemberian Health Education dengan media booklet tentang bahaya merokok efektif terhadap tingkat hubungan yang bermakna pada tingkat pengetahuan antara sebelum dan sesudah pendidikan kesehatan (Salafiah, 2014). Hasil penelitian Agustin tahun 2014 menyatakan bahwa terdapat perbedaan pengetahuan antara sebelum dan sesudah pendidikan karies gigi pada responden dengan media booklet $p$ value $=0,000$ (Agustin, 2014).

\section{Perbedaan Sikap antara Kelompok Intervensi dan Kontrol}

Hasil penelitian ini menemukan bahwa ada perbedaan skor sikap antara kelompok perlakuan dan kelompok kontrol setelah diberikan pemberdayaan sebagai jumantik PSN DBD. Siswa yang diberdayakan sebagai jumantik PSN memiliki skor sikap $(47,17 ; 95 \% \mathrm{Cl} 46,04-48,3)$ lebih tinggi dibandingkan dengan skor sikap 
$(44,23 ; 95 \% 41,8-46,66)$ siswa yang tidak diperdayakan sebagai JumantikPSN. Perbedaan rerata peringkat kedua kelompok tersebut bermakna secara statitik yang dinyatakan dalam nilai $p$ value $=0,014$ $(p<0,05)$. Hasil ini sejalan dengan penelitian Pratiwi tahun 2017 bahwa booklet efektif dan memberikan pengaruh signifikan dalam meningkatkan pengetahuan siswa tentang HIVIAIDS dengan $p$ value 0,006 dan sikap memiliki nilai $p$ value 0,005 (Pratiwi, 2017). Penelitian yang sesuai dengan hasil penelitian ini menunjukkan terdapat perbedaan sikap jumantik kecil sebelum dan sesudah Pelatihan pencegahan DBD di MIN Ketilang (Indrayani, 2010).

\section{Perbedaan Perilaku antara Kelompok Intervensi dan Kontrol}

Hasil penelitian ini menemukan bahwa ada perbedaan skor perilaku antara kelompok perlakuan dengan kelompok kontrol setelah diberdayakan jumantik PSN. Siswa yang diberdayakan sebagai jumantik PSN memiliki skor perilaku (mean rank 35,78 ) lebih tinggi dibandingkan dengan skor perilaku (mean rank 25,22) siswa yang tidak diberdayakan sebagai Jumantik PSN. Hasil penelitian ini sejalan dengan penelitian sebelumnya (Susiana, 2016). Pemberian konseling dengan booklet oleh apoteker secara signifikan membantu meningkatkan pengetahuan, perilaku dan kepatuhan pasien $(p<0,05)$. Pendidikan kesehatan sangat efektif dalam memengaruhi perilaku seseorang, karena didasarkan pada psikologi sosial, komunikasi massa, dan pemasaran untuk mengembangkan dan menyampaikan materi dan pesan pencegahan agar terhindar dari penyakit (Putri, 2017).

\section{Perbedaan Keberadaan Jentik antara Kelompok Kontrol dan Perlakuan}

Kelompok intervensi ditemukan hasil pemantauan jentik bahwa Negatif ABJ (angka bebas jentik) minggu ke-1 (50\%) dan pada minggu ke-8 meningkat menjadi $72 \%$, sedangkan pada kelompok kontrol minggu ke-1 (34\%) dan pada minggu ke-8 sedikit bertambah menjadi $(40,8 \%)$ ABJnya. Hasil dari uji hoptesis menggunakan analisis statistik chi square menunjukkan nilai signifikan $(0,004)<0,05$, yang artinya terdapat perbedaan keberadaan jentik di lingkungan rumah yang terdapat siswa jumantik aktif dengan lingkungan rumah yang tidak aktif di lingkungan kelurahan Panarung Palangka Raya. hasil ini sejalan dengan penelitian Andini tahun 2013 yang menggunakan uji Fisher dan hasilnya menunjukan significancy $0,007 \quad(p<0,05)$, bahwa terdapat perbedaan keberadaan jentik di sekolah dasar yang terdapat siswa pemantau jentik aktif dengan sekolah dasar yang tidak terdapat siswa pemantau jentik aktif di Sekolah Dasar Kecamatan Gajahmungkur tahun 2013 (Andini, 2013). Hasil penelitian lain yang sesuai yaitu pemberdayaan siswa pemantau jentik dapat meningkatkan angka bebas jentik pada pemantauan minggu keempat selama empat kali pemantauan (Susanna, dkk, 2019).

Pemantauan jentik secara rutin 1-2 kali seminggu oleh siswa pemantau jentik termasuk dalam fungsi controling dari manajemen. Kelompok eksperimen telah melakukan upaya dalam fungsi kontroling/ pengawasan dengan adanya Juru pemantau jentik-PSN Anak sekolah maka akan diperoleh data keberadaan jentik secara rutin sehingga evaluasi keberadaan jentik di sekolah dan rumah dilakukan secara tepat. Kegiatan PSN anak sekolah meliputi pengamatan jentik dan kegiatan 3M (menutup, menguras, memanfaatkan barang bekas) yang bernilai ekonomis 
dan gerakan ini merupakan kegiatan yang paling efektif mewujudkan kebersihan lingkungan dan perilaku ntuk mencegah terjadinya DBD sehingga mewujudkan kebersihan dan perilaku hidup sehat (Nasution, Sadono, \& Wibowo, 2018). Siswa Pemantau Jentik (sismantik) adalah pemberdayaan siswa sekolah dasar untuk menjadi juru pemantau jentik. Siswa berasal dari sekolah tersebut dengan kisaran umur 9-12 tahun, yang lebih tepatnya siswa kelas 5 SD. Siswa yang telah mampu membaca dan memahami apa yang mereka baca, lihat, dan dengar. Mereka memantau jentik di lingkungan sekolah. Kegiatan atau tugas siswa pemantau jentik dilakukan secara kelompok bergilir berdasarkan kelompok piket kebersihan kelas.

\section{SIMPULAN}

Hasil penelitian menunjukkan: (1) ada perbedaan skor pengetahuan antara kelompok kontrol dan intervensi, (2) ada perbedaan skor sikap antara kelompok kontrol dan intervensi, (3) ada perbedaan perilaku antara kelompok kontrol dan intervensi, (3) ada perbedaan angka keberadaan jentik antara kelompok kontrol dan intervensi. Hasil tersebut menunjukkan penggunaan booklet Jumantik-PSN berpengaruh terhadap pengetahuan, sikap, perilaku serta keberadaan jentik. Booklet dapat menjadi salah satu alternatif media edukasi untuk menyampaikan informasi yang berkaitan Jumantik-PSN anak sekolah sehingga dapat membantu meningkatkan pengetahuan, sikap, perilaku dan menurunkan keberadaan jentik. Kiranya pihak sekolah dapat memberdayakan anak sekolah yang sudah mendapatkan pelatihan Jumantik PSN dalam pemantauan jentik di lingkungan sekolah dan rumah masingmasing perserta didik.

\section{DAFTAR PUSTAKA}

Agustin, M. (2014). Efektifitas Pendidikan Kesehatan Media Booklet dibandingkan Audiovisual Terhadap Pengetahuan Orang Tua Tentang Karies Gigi Pada Anak di Desa Makah Haji (Skripsi). Universitas Muhammadiyah Surakarta.

Andini, A. (2013). Pengaruh Keberadaan Siswa Pemantau jentik Aktif Dengan Keberadaan Jentik di Sekolah Dasar Kecamatan Gajah Mungkur Kota Semarang. Unnes Journal of Public Health, 3(2).

Dinas Kesehatan Kalimantan Tengah. (2016). Profil Kesehatan 2016 Provinsi Kalimantan Tengah. Palangka Raya.

Departemen Kesehatan Republik Indonesia. (2005). Pencegahan dan pemberantasan demam berdarah dengue di Indonesia. Jakarta: Departemen Kesehatan Republik Indonesia.

Indrayani, A. D. (2010). Perbedaan Pengetahuan dan Sikap Jumantik KEcil Sebelum dan Sesudah Pemberian Pelatihan Pencegahan Demem Berdarah Dengue (DBD) di MIN Ketitang (Skripsi). Universitas Muhammadyah Surakarta, Surakarta, Indonesia.

Lapau, B. (2012). Metodologi Penelitian Kesehatan. Jakarta: Yayasan Pustaka Obor Indonesia.

Lemeshow, S., Hosmer, D., Klar, J., \& Lwanga, S. (1993). Adequacy of Sample Slze in Health Studies. Toronto: Published on Behalf of the World Health Organization by John Wiley Sons.

Malikatul, M. (2015). Pengaruh Pendidikan Kesehatan dengan Media Booklet terhadap Pengetahuan Nutrisi Ibu 
Laktasi di Wilayah Kerja Puskesmas Ciputat Timur. Universitas Muhammadiyah Surakarta.

Nasution, S., Sadono, D., \& Wibowo, C. T. (2018). Penyuluhan Kesehatan Untuk Pencegahan dan Risiko Penyakit DBD dalan Manga dan Infografis. Jurnal Penyuluhan, 14(1).

Pratiwi, D. A. (2017). Efektivitas Pemberian Booklet Terhadap Tingkat Pengetahuan dan Sikap Pencegahan HIV dan AIDS pada Remaja Siswa Kelas VIII di SMPN 1 Cangkringan Selaman. Universitas Aisyiyah Yogyakarta.

Pusdatin. (2017). Demam Berdarah Dengue. Jakarta.

Pusdatin. (2018). Situasi Demam Berdarah di Indonesia Tahun 2017. Jakarta.

Putri, R. (2017). Hubungan Antara Tingkat Pendidikan dan Tingkat Pengetahuan dengan Perilaku Hidup Sehat Kualitas Lingkungan Rumah. Universitas Lampung.

Salafiah, N. (2014). Pengaruh Pendidikan Kesehatan Terhadap Pengetahuan dan Sikap Ibu Tentang Pola Asuh Anak Usia Bayi di Wilayah Kerja Puskesmas Kartasura. Universitas Muhammadyah Surakarta.
Susanna, D., Ernawati, K., Ahmadi, U. F., Hasan, H., \& Ritawati. (2019). Sismantik : Siswa Pemantau Jentik Sekolah Dasar dalam Upaya Penurunan Kasus Demam Berdarah Dengue (DBD). Jurnal Pengabdian Kepada Masyarakat, 5(2).

Susiana, A. (2016). Efektivitas Pemberian Konseling Melalui Booklet Terhadap Peningkatan Pengetahuan, Perilaku, kepatuhan dan Penurunan Tekanan Darah pada Penderita Hipertensi di Puskesmas Purworejo (Tesis). Universitas Gadjah Mada.

Wahyuni, L. (2016). Efektifitas Health Education (HE) Media Booklet tentang Bahaya Merokok terhadap Tingkat Pengetahuan Remaja di SMPN 1 Mojoanyar. Jurnal Keperawatan Bina Sehat, 13(1). 